\title{
An overview of the Biosphere Reserve concept and its application to Nepal
}

\begin{abstract}
Shree Gopal Jha ${ }^{1}$
The present paper provides an overview on the concepts of biosphere reserves. The biosphere reserve concept has been developed within the framework of the UNESCO's Programme on Man and Biosphere (MAB). The paper spells out definition, objectives, characteristics, function, beneficiaries, structure and design, and criteria for the selection of Biosphere Reserves etc.
\end{abstract}

Key words: Biosphere reserve, conservation, ecosystem, conservation

$\mathbf{T}$ he concept of Biosphere Reserves (BRs) was initiated by the United Nations Educational Scientific and Cultural Organization (UNESCO) in the year 1970 to facilitate resolution of increasing conflict between people and the protected areas. The approach emphasizes the importance of the structure and functioning of ecological systems and their mode of reaction when exposed to human intervention including impact of man on the environment and vice-versa. Man and Biosphere is primarily a programme of research and training and seeks scientific information to find solution of concrete practical problems of management and conservation. By December 1998, 90 countries have designated 356 Biosphere Reserves all over the world. With the cooperation of state Government, India has also designated 11 Biosphere Reserves till October 1999.

In Nepal Man and Biosphere Reserve is a new concept. So far, no Biosphere Reserve has been declared yet. About $19.4 \%$ of the total area of the country $(147,181$ sq. m.) representing all ecological regions (Terai, Mid-hills, High Mountains and Himalayas) is under protected area system. There are 9 National parks, 3 Wildlife Reserves, 3 Conservation Areas, 1 Hunting Reserve and 9 Buffer Zones representing major ecosystems. Recently, the UNESCO's MAB Committee in Nepal had initiated an activity to design the first Biosphere Reserve in the Country. A working committee consisting of wellqualified personnel involved in the protected area management, forestry, university and other conservation sectors was formulated for this purpose. Langtang National Park was unanimously chosen as the potential Biosphere Reserve in the country based on the general criteria for an area to be qualified for designation as a Biosphere Reserve and is under process in the Ministry for the declaration of Biosphere Reserve in Nepal.

\section{What is Biosphere Reserve (BR)?}

$\mathrm{BR}$ is an International designation made by UNESCO for representative parts of natural cultural landscapes extending over large area of terrestrial or coastal/ marine ecosystems or a combination thereof. Biosphere Reserves (BRs) are designated to deal with one of the most important questions of reconciling the conservation of biodiversity, the quest for economic and social development and maintenance of associated cultural values. These areas are internationally recognized within the framework of UNESCO's Man and Biosphere programme after receiving consent of the participating country.

\section{Objectives of Biosphere Reserve}

It may be noted that BRs are not a substitute or alternative, but a re-enforcement to the existing protected areas. The objectives of the Biosphere Reserve Programme, as envisaged by the core Group of Experts are as follows.

- To conserve the diversity and integrity of plants and animals within natural ecosystems;

- To safeguard genetic diversity of species on which their continuing evolution depends;

- To provide areas for multi-faceted research and monitoring;

- To provide facilities for education and training; and

- To ensure sustainable use of natural resources through most appropriate technologies for improvement of economic livelihood of the local people. 
These objectives should be oriented in such a way that BRs are the units wherein the biological, socioeconomic and cultural dimensions of conservation are integrated together into realistic conservation strategies.

\section{Characteristics of Biosphere Reserves}

1. Biosphere Reserves are protected areas of land/ or coastal environments wherein people are an integral component of the system. Together, they constitute a world-wide network linked by International understanding for exchange of scientific information.

2. The network of BRs includes significant examples of biomes throughout the world.

3. Each BR includes one or more of the following categories: -

(i) BRs are Representative examples of natural biomes.

(ii) BRs conserve unique communities of biodiversity or areas with unusual natural features of exceptional interest. It is recognized that these representative areas may also contain unique features of landscapes, ecosystems and genetic variations e.g. one population of a globally rare species; their representativeness and uniqueness may both be characteristics of an area.

(iii) BRs generally have a non-manipulative core area, in combination with areas in which baseline measurements, experimental and manipulative research, education and training is carried out. Where these areas are not contiguous, they can be associated in a cluster.

(iv) BRs generally have a non-manipulative core area, in combination with area in which baseline measurements, experimental and manipulative research, education and training is carried out. Where these areas are not contiguous, they can be associated in a cluster

4. Each BR should be large enough to be an effective conservation unit, and to accommodate different uses without conflict.

5. BRs provide opportunity for monitoring, research, education and training on natural and managed ecosystems. They will have particular value as benchmarks or standards for measurement of long -term changes in the BR as a whole.

6. A BR must have adequate long-term legal protection.

7. In some cases, BRs coincide with, or incorporate, existing or proposed protected areas, such as National Parks, Sanctuaries or Nature Reserves. The concept has the great advantage of being flexible and it is likely that it will continue to evolve as experience grows.

8. Each BR exemplifies voluntary cooperation to conserve and use resources for the well being of people at local, national, regional and global levels.

9. BR is a system where planners, scientists, managers, and local people participate in evolving integrated programme to manage land and water to meet human needs and at the same time conserving natural processes and ecological resources through sustainable resources use, which does not reduce the future use potential of the resources. Maintenance of long-term health of representative ecosystems is the ultimate goal of BRs, which will ensure survival of future human generations.

\section{Functions of Biosphere Reserves}

Each Biosphere Reserve is intended to fulfill following three basic functions which are complementary and mutually reinforcing :-

(a) Conservation:

- To ensure the conservation of landscapes ecosystems, species and genetic variations;

- To encourage the traditional resource use systems;

- To understand the patterns and processes of functioning of ecosystems;

- To monitor the natural and human caused changes on spatial and temporal scales.

(b) Development

- To promote, at the local level, economic development which is culturally, socially and ecologically sustainable;

- To develop the strategies leading to improvement and management of natural resources. 
(c) Logistics support

- To provide support for research, monitoring, education and information exchange related to local, national and global issues conservation and development;

- Sharing of knowledge generated by research through site specific training and education;

- Development of community spirit in the management of natural resources

\section{Beneficiaries}

Beneficiaries of Biosphere Reserve are local people, scientists, government decision makers and the world community.

\section{Structure and Design of Biosphere Reserves}

To carry out the complementary activities of natural conservation and use of natural resources, biosphere reserves are organized or demarcated into 3 interrelated zones. These are (i) Natural or Core Zone, (ii) Buffer Zone (iii) Transition or Restoration Zone.

(i) The Core Zone:

The Core Zone is kept absolutely undisturbed. It must contain suitable habitat for numerous plant and animal species, including higher order predators and may contain centers of endemism. Core areas often conserve the wild relatives of economic species and also represent important genetic reservoirs. The Core Zone also contains places of exceptional scientific interest. A Core Zone secures legal protection and management and research activities that do not affect natural processes and wildlife are allowed. Strict nature reserves and wilderness portions of the site are designated as Core areas of BR. The Core Zone is to be kept free from all human pressures external to the system.

(ii) The Buffer Zone

In the Buffer Zone, which adjoins or surrounds Core Zone, uses and activities are managed in ways that protect the core Zone. These uses and activities include restoration, demonstration sites for enhancing value addition to the resources, limited recreation, tourism, fishing, grazing etc which are permitted to reduce its effect on Core Zone. Research and educational activities are to be encouraged. Human activities are likely to continue if these do not adversely affect the ecological diversity. In Buffer Zone, manipulative macro-management practices are used. Experimental research areas are used for understanding the patterns and process in ecosystem. Modified or degraded landscapes are included as rehabilitation areas to restore the ecology in a way that it returns to sustainable productivity.

(iii) The transition zone

The transition area is the outermost part of a Biosphere Reserve. This is usually not delimited one and is a Zone of cooperation where conservation knowledge and management skills are applied and uses are managed in harmony with the purpose of the Biosphere Reserve. This includes settlements, crop lands, managed forests and area for intensive recreation and other economic uses characteristics of the region. Existing legally protected areas (National Parks, Wildlife Sanctuaries, Wildlife Reserves/Protected Forests) may become part of the BR without any change in their legal status.

\section{Criteria for selection of sites for BRs}

\section{Primary criteria :-}

- A sites that must contain an effectively and minimally disturbed core area of value of nature conservation and should include additional land or water suitable for research and demonstration of sustainable methods of research and management;

- The core area should be typical of a biogeographical unit and large enough to sustain viable populations representing all tropic levels in the ecosystem;

- The management authority must ensure encouragement to research and monitoring and enlist cooperation of the local and regional understanding in planning and managing the area for conservation and human benefit.

\section{Secondary criteria :-}

- Areas having rare and endangered species;

- Areas having diversity of soil and micro-climatic conditions and indigenous varieties of biota;

- Areas potential for preservation of traditional tribal or rural modes of living for harmonious use of environment. 


\section{Conclusion}

Nepal has, so far, 9 National Parks, 3 Wild life Reserves, 3 Conservation Areas, 1 Hunting Reserve and 9 Buffer zones representing major ecosystems. Most of the National Parks and Reserve Areas meet the criteria of the Biosphere Reserve developed within the UNESCO Program. But before declaration of any protected areas as Man and biosphere Reserve in Nepal, a separate clear Act and Legislation concerning this should be formulated first so as to declare the Biosphere Reserve which is not yet started in Nepal.

\section{References}

Dela Jinie, Silva Asoka de, Amarasinghe Anusha and Wijesinghe Leslie (2002). The South and Central Asian Man and The Biosphere Meeting of Experts on Environmental Conservation, Management and Research -Summary Report.

MOEF New Delhi (1999). Guidelines for

Protection, Maintenance, Research and Development in the Biosphere Reserves in India.

SACAM (2003). South and Central Asia Man and Biosphere Network Newsletter, 2nd Issue, October, 2003 